\title{
Structural equation modeling approach to the diversity-productivity relationship of Wadden Sea phytoplankton
}

\author{
Dorothee Hodapp ${ }^{1, *}$, Sandra Meier ${ }^{2}$, Friso Muijsers ${ }^{1}$, Thomas H. Badewien ${ }^{3}$, \\ Helmut Hillebrand ${ }^{1}$
}

\author{
${ }^{1}$ ICBM-Terramare, University of Oldenburg, Schleusenstr. 1, 26382 Wilhelmshaven, Germany \\ ${ }^{2}$ Department of Geosciences and Geography, University of Helsinki, PO Box 64 (Gustaf Hällströmin katu 2a), \\ 00014 University of Helsinki, Finland \\ ${ }^{3}$ ICBM, University of Oldenburg, Carl-von-Ossietzky-Straße 9-11, Postfach 2503, 26111 Oldenburg, Germany
}

\begin{abstract}
Biodiversity-ecosystem functioning (BEF) research has been a major topic in ecology for over 2 decades, and recent meta-analyses have confirmed biodiversity to be a driver of ecosystem processes and services. To date, the vast majority of BEF studies have been conducted experimentally, and it is unclear whether their outcomes can be transferred to natural communities and ecosystems. The major challenge faced in the analysis of observational data is to incorporate direct and indirect processes which influence the response variable of interest. Consequently, the statistical methods used to analyze such relationships must accommodate the multivariate nature of these data. One multivariate approach, viz. structural equation modeling, has already been applied to BEF research in terrestrial and freshwater ecosystems. In this study, we applied a structural equation model to monitoring data on marine phytoplankton communities, including data on environmental parameters, community structure, and measures of productivity. Our aim was to ascertain whether similar patterns and processes driving BEF relationships as described for other ecosystem types are evident in marine phytoplankton communities. We found that different aspects of biodiversity (richness, evenness) are significantly linked to ecosystem functions (productivity, resource use efficiency). These relationships are embedded in a multitude of direct and indirect links between environmental factors, community diversity, and productivity. Overall, our analysis confirms patterns observed in terrestrial and freshwater ecosystems and highlights the importance of incorporating multivariate methods for a better understanding of BEF processes in natural ecosystems.
\end{abstract}

KEY WORDS: Multivariate - Resource use efficiency - Evenness - Partial least squares · Monitoring $\cdot$ Biodiversity-ecosystem functioning

\section{INTRODUCTION}

In the face of an unprecedented rate of change in biodiversity worldwide (Pimm et al. 2014), the question of why we are losing species at such a rapid pace and the estimation of possible consequences of this decline have turned into a major research topic in ecology. Large-scale grassland experiments in the early 1990s suggested that a loss of diversity might have detrimental effects on the dynamics and functioning of ecosystems (Naeem et al. 1995, Tilman et al. 1996). Twenty years later, a huge number of experimental and theoretical studies exploring the relationship between diversity and the rate and stability of several ecosystem processes have considerably improved our understanding of the main underlying 
processes (Balvanera et al. 2006, Cardinale et al. 2006).

Cardinale et al. (2012) recently summarized the experimental evidence for biodiversity as a driver of ecosystem processes and services. Based on hundreds of experiments, they concluded that there is unanimous evidence for positive effects of biodiversity on resource capture and the resultant enhanced biomass production within trophic groups. This evidence is based mainly on experimental studies with artificially maintained biodiversity gradients, thus generating debate regarding the transferability of the results to natural ecosystems. Indeed, coexistence mechanisms determining natural species composition and mechanisms relating diversity to functions may differ (Hillebrand \& Matthiessen 2009). Also, most studies have analyzed richness as a sole measure of biodiversity, although effects mediated by evenness have been commonly reported in field studies (Hillebrand et al. 2008). Finally, all of the described mechanisms potentially act on different temporal and spatial scales and can therefore rarely be understood out of context (Cardinale et al. 2009), making generalizations difficult.

To date, only a few studies have addressed the challenge of validating experimentally derived the- ories with data from natural aquatic ecosystems. The first 2 columns of Fig. 1 give an overview of these studies and their hypothesized biodiversityecosystem functioning (BEF) patterns. Ptacnik et al. (2008) analyzed over 3000 phytoplankton samples from Scandinavian lakes over vast environmental gradients and found that resource use efficiency (RUE) and its stability were directly related to species diversity. Korhonen et al. (2011) investigated productivity-diversity relationships in boreal lakes in Scandinavia, considering additional influences of spatial scale dependency, resource availability, and environmental factors. While acknowledging the significant effects of these external factors on phytoplankton biomass and the productivity-diversity relationship, positive effects of species richness on biomass production were also evident. Filstrup et al. (2014) analyzed long-term data from lake ecosystems on diversity and biomass across trophic levels. In their study, phytoplankton evenness showed negative correlations with RUE and biomass production at the producer level, but positive correlations with RUE at the consumer level (zooplankton). At the same time, RUE on both levels increased with increasing species richness at both levels.

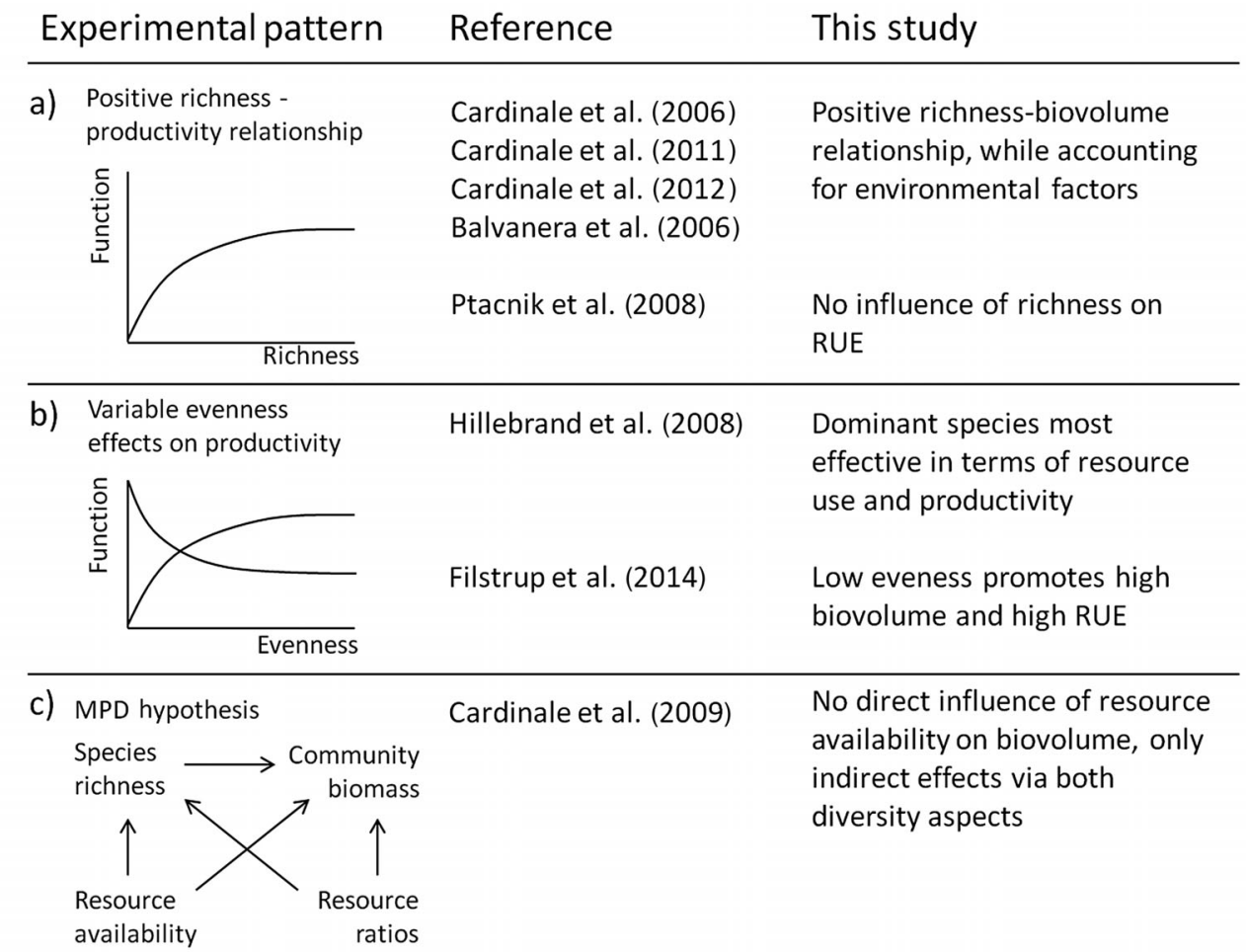

Fig. 1. Summary of biodiversity-ecosystem functioning (BEF) patterns (column 1) tested in earlier studies (column 2) and comparison with the results obtained from the structural equation model in this study (column 3). RUE: resource use efficiency; MPD: multivariate productivity diversity hypothesis 
Despite these case studies, ecologists face both methodological and mechanistic challenges when disentangling the multiple simultaneous pathways that drive biodiversity and ecosystem functioning in natural ecosystems. Due to the multivariate nature of most ecological data, the methodology applied to assess fundamental mechanisms must accommodate the multivariate nature of these dependencies, as well as direct and indirect influences. Structural equation models (SEMs) represent a multivariate approach capable of dealing with such interdependencies (Arhonditsis et al. 2006, Grace et al. 2010). By allowing for the integration of several processes in a single model, SEMs provide a framework for the analysis of multivariate hypotheses that can incorporate more flexible networks of interactions than any bivariate approach. Cardinale et al. (2009) used an SEM approach to explain productivity-diversity relationships of phytoplankton communities in Norwegian lakes, combining aspects of species energy theory and resource ratio theory. They found a network of direct and indirect pathways relating resource availability, resource ratios, and species richness to the amount of biomass produced (multivariate productivity diversity hypothesis, MPD).

In this study, we applied an SEM to a monitoring data set of intertidal phytoplankton communities. Our study is the first to extend a multivariate approach to a marine natural ecosystem to address the following questions: (1) What are the drivers of phytoplankton productivity? (2) Do we find similar BEF relationships and mechanisms in a highly dynamic ecosystem influenced by tides and currents as in lake and grassland ecosystems? (3) Can these patterns be related to or explained by theoretical concepts like enhanced RUE in more diverse communities (Ptacnik et al. 2008)?

\section{MATERIALS AND METHODS}

\section{Data}

The 3 study sites (Stn 1: $53^{\circ} 45^{\prime} 01.00^{\prime \prime} \mathrm{N}, 007^{\circ} 40^{\prime}$ $16.30^{\prime \prime} \mathrm{E}_{\text {; }}$ Stn 2: $53^{\circ} 43^{\prime} 75.70^{\prime \prime} \mathrm{N}, 007^{\circ} 42^{\prime} 42.80^{\prime \prime} \mathrm{E}_{\text {; }}$ Stn 3: $53^{\circ} 43^{\prime} 38.90^{\prime \prime} \mathrm{N}$, $007^{\circ} 43^{\prime} 58.40^{\prime \prime} \mathrm{E}$ ) are located in a tidal flat between the northwest coast of Germany and a back barrier island located a few kilometers offshore. The area is characterized by semidiurnal tides (tidal range $2.2-2.8 \mathrm{~m}$ ), which regularly flood about $80 \%$ of the tidal flats with water carrying high suspended matter loads from the North Sea. Current velocities of up to $1.8 \mathrm{~m} \mathrm{~s}^{-1}$ cause vertical and horizontal mixing of the water column (Reuter et al. 2009). Samples were taken from 3 different depths, viz. $1 \mathrm{~m}$ and $6 \mathrm{~m}$ below the water surface and $1 \mathrm{~m}$ above the sea floor, which is at a water depth of between 9 and $10 \mathrm{~m}$ in this area. In order to prevent variation in community composition due to the tidal cycle, all samples were taken during half-tide with incoming flood.

Our data set consists of phytoplankton samples taken approximately twice a week between March and December 2009, resulting in a total of 101 samples (see Supplement 1 at www.int-res.com/articles/ suppl/m523p031_supp.pdf). Apart from phytoplankton samples, measurements of the following environmental parameters were taken at each sampling occasion and site: oxygen saturation, dissolved $(\mathrm{N}, \mathrm{P}, \mathrm{Si})$ and particulate $(\mathrm{C}, \mathrm{N}, \mathrm{P})$ nutrients, water temperature, conductivity, salinity, density, turbidity, and redox potential (see Supplement 1). A multi-water sampler (HYDRO-BIOS) with 3.5 l Niskin bottles was used to collect water samples. The sampler was equipped with a CTD probing system with sensors for measuring pressure, conductivity, and temperature, from which salinity and density were derived (UNESCO 1985). Subsamples (250 $\mathrm{ml}$ ) from each Niskin bottle were frozen immediately, stored at $-20^{\circ} \mathrm{C}$, and then used for photometrical nutrient analysis (Autoanalyzer SAN ++, Skalar). Data on photosynthetically active radiation (PAR), wind direction, and wind speed were supplied by a permanently installed time-series station nearby (Grunwald et al. 2007, Reuter et al. 2009). Consequently, these parameters are represented with the same value for all 3 sampling locations per day, which is justified as large differences in weather conditions are unusual in the study area.

For species identification, $100 \mathrm{ml}$ subsamples were preserved in $1 \%$ Lugol's iodine solution and stored in brown glass bottles. The organisms in 1 and $5 \mathrm{ml}$ subsamples were counted for each sample in order to ensure the detection of rare species in the $5 \mathrm{ml}$ subsample. Due to high amounts of detritus and sediment in all samples, smaller (benthic) species had to be counted in the $1 \mathrm{ml}$ subsample. Phytoplankton organisms were determined to the lowest possible taxonomic level, using an inverted microscope (Zeiss, Axiovert 10) (Utermöhl 1958). The dimensions of simple geometrical bodies of 20 cells of each dominant taxon were measured and used for calculation of specific cellular volumes according to Hillebrand et al. (1999). Cell volumes of rare taxa were taken from the HELCOM phytoplankton check list (Olenina et al. 2006). 


\section{Data analysis}

We calculated RUE for nitrogen and phosphorus as phytoplankton biovolume per unit of available nutrient (Ptacnik et al. 2008, Striebel et al. 2009), e.g. for nitrogen:

$$
\begin{gathered}
\operatorname{RUE}_{\mathrm{N}}=\text { biovolume }\left(\mu \mathrm{m}^{3} \mathrm{ml}^{-1}\right) / \\
\text { [dissolved + particulate } \left.\mathrm{N}\left(\mu \mathrm{mol} \mathrm{l}^{-1}\right)\right]
\end{gathered}
$$

In order to condense the environmental variables to a smaller number of biologically meaningful factors and use these as latent variables in the SEM, we analyzed the corresponding correlation matrices and applied exploratory factor analysis (Harman 1976) using basic functions of the statistics software R 3.0.0. (R Development Core Team 2010; see Supplement 2).

For implementation and evaluation of the SEM, we applied the open source software smartPLS (Ringle et al. 2005). SmartPLS employs an alternative to the often-used covariance-based SEM approach and is especially suitable for cases in which data are not normally distributed or sample sizes are small (Götz et al. 2010), which both apply to our data set. Partial least squares (Lohmöller 1989) path models maximize the variance of endogenous latent variables explained by the independent variables. The partial model relationships are estimated iteratively applying ordinary least squares regression (Haenlein \& Kaplan 2004, Esposito Vinzi et al. 2010). For more details on the methodology and application, see Supplement 3.

\section{Model set up}

\section{Structural model}

The structural model depicts the direct and indirect relationships between the latent variables. Our general expectation, based on the findings reported by Cardinale et al. (2009) and Ptacnik et al. (2008), was to find evidence suggesting that the environmental factors and nutrient availability affect ecosystem functioning (biovolume and RUE) directly and indirectly via diversity aspects (richness and evenness). For the initial model structure, we therefore implemented 4 exogenous latent variables describing the physical environment and amount of nutrients in the sys- tem. These were solar energy, kinetic energy, chemical conditions, and the variable nutrients representing the amount of unconsumed nutrients in the water body (Fig. 2). Two endogenous latent variables (richness and evenness) described diversity characteristics of the phytoplankton community, and 2 endogenous variables (biovolume and RUE) represented the functional ecosystem aspects. For the initial model structure, we assumed direct causal pathways from the environmental variables to all structural and functional aspects as well as to nutrient availability. The observed parameters indicating the chemical conditions such as salinity are known to affect species composition as well as richness (Braarud 1951, Lionard et al. 2005), whereas redox potential and the related measurements of oxygen saturation can significantly influence the amount of phosphorus resuspension from the sediment (Schallenberg \& Burns 2004), thus affecting nutrient availability. Kinetic energy, here expressed by measurements of wind speed, velocity, and turbidity, causes mixing of the water body, which can result in a higher proportion of benthic species in the whole water column and is therefore likely to affect species composition and richness. Sedimented nutrients are also affected by sediment resuspension and mixing depth (Diehl 2002). Solar energy is tightly related to seasonal cycles regulating phytoplankton dynamics. Light is an important resource, and temperature affects phytoplankton growth rates as well as nutrient mineralization rates (Thamdrup et al. 1998, Colijn \& van Beusekom 2005, Boyd et al. 2013). As a consequence, we also assumed direct effects of solar energy on biovolume and RUE. Nutrient limitation leads to competitive exclusion of species and hence to changes in community compo-

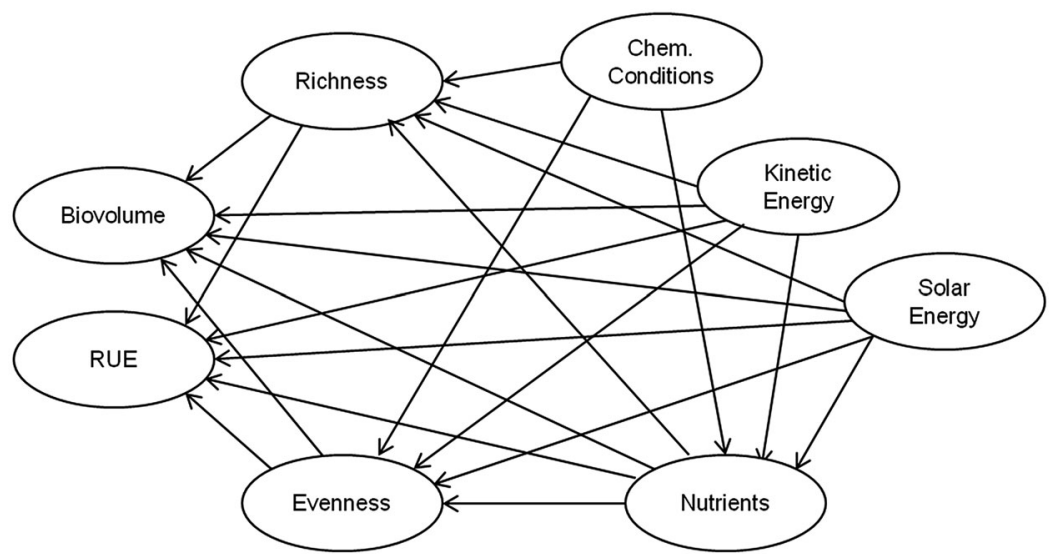

Fig. 2. Initial model structure according to assumptions. Only latent variables are displayed; indicator variables were omitted due to readability. Arrows depict causal pathways 
sition (Interlandi \& Kilham 2001, Vallina et al. 2014). Apart from the indirect effects of nutrient limitation mediated by these shifts in species diversity, we also expected direct effects of nutrient availability on biomass production as commonly reported in the literature (Cardinale et al. 2009). We did not specify a direct link between RUE and biovolume, as suggested by Ptacnik et al. (2008), in our model, because the RUE values were derived using the biovolume measurements (see Eq. 1) and the 2 variables are therefore likely to be correlated. As a consequence, the distinction between effects due to this constructed correlation, as opposed to correlation caused by BEF patterns, is unfeasible and interpretation difficult.

\section{Measurement model}

The measurement model specifies the relationship between the observable or indicator variables and the latent constructs (Supplement 1). Based on the correlation and factor analysis, we aggregated the 9 environmental parameters resulting in 3 higher-level categories, serving as latent constructs in the model: solar energy (PAR, water temperature, conductivity), kinetic energy (wind velocity, wind direction, turbidity), and chemical conditions (redox potential, density, salinity).

Species richness and genus richness were used as indicator variables for the latent variable richness, whereas Pielou's evenness (Pielou 1966) and the Shannon index (Shannon \& Weaver 1949) values served as indicators for evenness. Due to a small number of data points with biovolume values several magnitudes higher than the average, the biovolume data were log-transformed. Total biovolume, which includes the biovolume measures of pelagic as well as benthic phytoplankton species, and the biovolume of only pelagic species were employed as manifest variables for the latent construct biovolume.

For particulate nutrients, we only had measurements of N and P, but not Si. Consequently, RUE calculations were only possible for the first 2 nutrients, which then served as indicators for the latent variable. However, as Si represents an important and at times limiting resource for diatoms (Egge \& Aksnes 1992, Martin-Jézéquel et al. 2000), which are the dominant species in this area (Reid et al. 1990), we included dissolved inorganic $\mathrm{Si}$ with dissolved inorganic $\mathrm{P}$ and $\mathrm{N}$ as indicators for nutrient availability. With regard to model interpretation, it should be noted that the content of dissolved inorganic nutri- ents taken here represents the nutrient fraction which has not been consumed yet.

We tested for influences of sampling depth, but apart from a very weak negative correlation of depth with biovolume and a significant correlation with hydrostatic pressure, we did not detect sampling depth effects on the remaining variables. As pressure did not impact any of the variables of interest, both variables, pressure and sampling depth, were excluded from the model.

SmartPLS returns standardized path coefficients. Hence, the size of path coefficients can be directly compared and interpreted as the estimated change in an endogenous latent variable for 1 unit of change in an exogenous variable.

Although partial least squares regression is capable of dealing with multi-collinearity better than ordinary regression (Wold et al. 1984, Abdi 2007), it is recommended to check for high multi-collinearity among exogenous latent variables. For this purpose, we calculated variance inflation factors (VIFs). These quantify the amount of variance inflation of regression coefficient estimates due to multi-collinearity.

\section{RESULTS}

In total, 142 species were identified, of which 13 could only be roughly characterized according to their shape and size. Species richness and genus richness per sample varied between 30 and 70 species and 22 and 46 genera. The highest biovolume values were measured in spring, although single peak values (not consistent across depths) were measured throughout the year. Apart from salinity (no seasonal pattern as influenced by weather conditions), pressure (depth-related), $\mathrm{O}_{2}$ saturation, and redox potential (slight increase throughout the year), all other environmental variables showed typical seasonal patterns.

The final model revealed significant effects of 4 exogenous latent variables on biovolume values (Fig. 3). Solar energy (0.243), kinetic energy $(0.172)$, and richness $(0.146)$ yielded positive path coefficients of intermediate magnitude, whereas evenness showed a significantly negative correlation with biovolume (-0.932) and RUE (-0.657). This suggests a positive influence of the number of species on biovolume values, but even larger positive effects of the dominance of a few species on biovolume values and the conversion of nutrients into new biomass. No other significant effects on RUE were detected. 


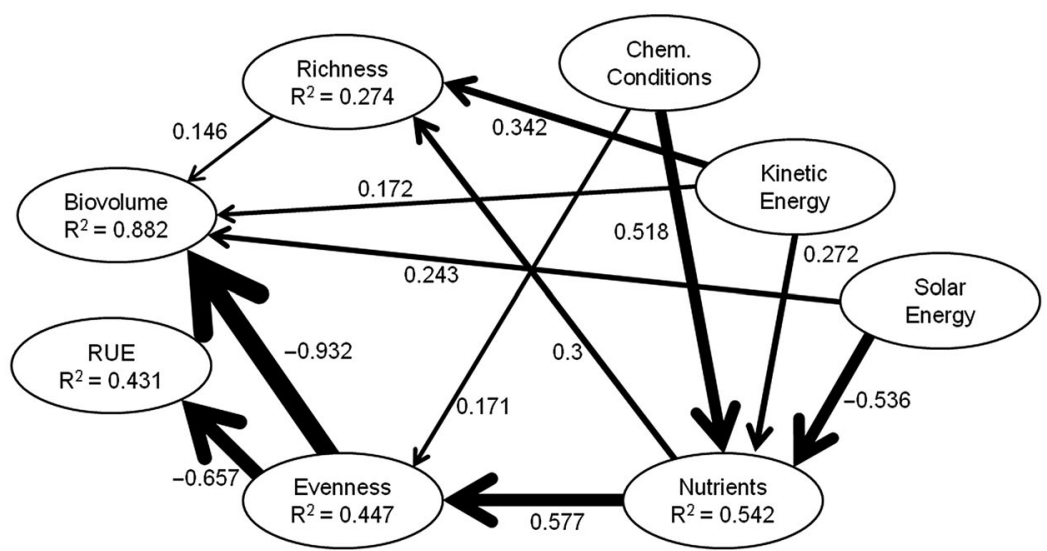

Fig. 3. Final structural model. Only significant pathways are displayed. Arrow width is set according to the significance of the causal pathway. Path coefficients are placed next to corresponding pathways. $\mathrm{R}^{2}$ values are displayed for all endogenous variables. RUE: resource use efficiency

Evenness itself showed a positive correlation with nutrient availability (0.577), indicating that dominance of a few species increases with the level of resource limitation. Another less pronounced but also positive effect (0.171) was detected for chemical conditions on the level of evenness in the phytoplankton communities.

The second diversity aspect, richness, was also correlated with nutrient availability. Here, species and genus richness decreased with decreasing nutrient levels, confirming that some species are better able to cope with nutrient limitation and therefore dominate, as indicated by the positive correlation between evenness and nutrient availability. Kinetic energy (0.342) showed similar positive effects on species richness as nutrient availability (0.3).

Finally, in terms of nutrient availability the model indicates significant correlations between each of the environmental variables (solar energy, kinetic energy, chemical conditions) and nutrient levels. The warmer the water and the more PAR is supplied, the fewer nutrients tend to be left in the water column. At the same time, larger amounts of nutrients were measured when redox potential, salinity, and kinetic energy exhibited high values.

In evaluating the model, we found that the values of the VIFs for all exogenous variables ranged from
1.008 to 1.375 , well below the threshold value of 5 (O'Brien 2007), indicating negligible need to account for multicollinearity issues within this model.

For calculation and interpretation of the following evaluation criteria, refer to Supplement 3. The outer loadings for all indicator variables are presented in Table 1. Apart from the loadings of salinity (0.579), all other values exceeded the recommended threshold value of 0.7 (Götz et al. 2010). A removal of indicators with values between 0.4 and 0.7 is only recommended when their deletion results in a significant improvement of the average variance extracted (AVE) values of the corresponding construct (Hulland 1999). The exclusion of salinity from the model did not yield a considerable improvement in the AVE value. On the other hand, a removal of $\mathrm{O}_{2}$ saturation caused an increase of the AVE value from 0.4507 to 0.6376 (above the threshold value), and the parameter was therefore excluded from the model. Table 2 summarizes the remaining evaluation measures. The AVE values for the single latent constructs were all well above 0.5 (Götz et al. 2010), indicating convergent validity. The results for composite reliability and

Table 1. Outer loadings of all measurement models. Outer loadings only exist for relationships between latent variables (columns) and their respective manifest variables (rows). All remaining cells are left blank. PAR: photosynthetically active radiation; RUE N (RUE P): resource use efficiency for nitrogen (phosphorus); Wvel: wind velocity; DIN: dissolved inorganic nitrogen; DIP: dissolved inorganic phosphorus; DISi: dissolved inorganic silica; log_totbiovol: logarithmic total biovolume; log biovol_pel: logarithmic biovolume of pelagic species

\begin{tabular}{|c|c|c|c|c|c|c|c|c|}
\hline & $\begin{array}{c}\text { Bio- } \\
\text { volume }\end{array}$ & $\begin{array}{c}\text { Even- } \\
\text { ness }\end{array}$ & RUE & $\begin{array}{l}\text { Solar } \\
\text { energy }\end{array}$ & $\begin{array}{l}\text { Kinetic } \\
\text { energy }\end{array}$ & $\begin{array}{l}\text { Chem. } \\
\text { cond. }\end{array}$ & $\begin{array}{l}\text { Diver- } \\
\text { sity }\end{array}$ & $\begin{array}{l}\text { Nut- } \\
\text { rients }\end{array}$ \\
\hline Evenness Index & & 0.9991 & & & & & & \\
\hline Genus richness & & & & & & & 0.9722 & \\
\hline PAR & & & & 0.9215 & & & & \\
\hline RUE N & & & 0.9570 & & & & & \\
\hline RUE P & & & 0.9454 & & & & & \\
\hline Redox & & & & & & 0.9695 & & \\
\hline Richness & & & & & & & 0.9679 & \\
\hline Salinity & & & & & & 0.5796 & & \\
\hline Shannon & & 0.9991 & & & & & & \\
\hline Temp & & & & 0.8755 & & & & \\
\hline Turbidity & & & & & 0.9414 & & & \\
\hline Wvel & & & & & 0.7831 & & & \\
\hline DIN & & & & & & & & 0.8350 \\
\hline DIP & & & & & & & & 0.7879 \\
\hline DISi & & & & & & & & 0.8127 \\
\hline Log_totbiovol & 0.9974 & & & & & & & \\
\hline Log_biovol_pel & 0.9974 & & & & & & & \\
\hline
\end{tabular}


Table 2. Evaluation criteria for the validity assessment of the ency; AVE: average variance extracted

\begin{tabular}{|lccc|}
\hline & AVE & $\begin{array}{c}\text { Composite } \\
\text { reliability }\end{array}$ & $\begin{array}{c}\text { Cronbach's } \\
\text { alpha }\end{array}$ \\
\hline Biovolume & 0.9949 & 0.9974 & 0.9948 \\
Evenness & 0.9982 & 0.9991 & 0.9982 \\
RUE & $0-9048$ & 0.9500 & 0.8952 \\
Solar energy & 0.8079 & 0.8937 & 0.7648 \\
Kinetic energy & 0.7497 & 0.8559 & 0.6907 \\
Chemical conditions & 0.6379 & 0.7681 & 0.5316 \\
Diversity & 0.9410 & 0.9696 & 0.9374 \\
Nutrients & 0.6595 & 0.8531 & 0.7424 \\
\hline
\end{tabular}

Table 3. Fornell-Larcker criterion. For calculation and interpretation of the criterion, refer to Supplement 3 at www.int-res.com/articles/suppl/m523p031_supp.pdf. RUE: resource use efficiency

\begin{tabular}{|lccccccc|}
\hline Biovolume & $\begin{array}{c}\text { Even- } \\
\text { ness }\end{array}$ & RUE & $\begin{array}{c}\text { Solar } \\
\text { energy }\end{array}$ & $\begin{array}{c}\text { Kinetic } \\
\text { energy }\end{array}$ & $\begin{array}{c}\text { Chemical } \\
\text { conditions }\end{array}$ & Diversity Nutrients \\
\hline 0.9949 & & & & & & & \\
0.7723 & 0.9982 & & & & & & \\
0.5622 & 0.4313 & 0.9048 & & & & & \\
0.1582 & 0.0452 & 0.0163 & 0.8079 & & & & \\
0.0004 & 0.0755 & 0.0010 & 0.0002 & 0.7497 & & & \\
0.1269 & 0.1751 & 0.0584 & 0.0438 & 0.0075 & 0.6379 & & \\
0.0231 & 0.1120 & 0.0466 & 0.0717 & 0.1933 & 0.0014 & 0.9410 & \\
0.3727 & 0.4229 & 0.1354 & 0.1865 & 0.1051 & 0.1841 & 0.1691 & 0.6595 \\
\hline
\end{tabular}
measurement part of the model. RUE: resource use effici-

the biovolume values ( $\mathrm{R}^{2}$ of 0.8823$)$. Approximately half of the variation in RUE, evenness, and nutrient availability could be explained by their exogenous variables, which is considered acceptable for ecological data. The $\mathrm{Q}^{2}$ values for productivity, RUE, evenness, and nutrients also indicated large predictive power for these latent constructs and intermediate predictive relevance for diversity. The effect size $\left(\mathrm{f}^{2}\right)$ values for any possible pair of exogenous and endogenous latent construct are presented in Table 5. The calculated effect sizes indicated a strong influence of community evenness and solar energy on biovolume, as well as high impacts of nutrients on evenness. Nutrients themselves were strongly affected by solar energy and chemical conditions according to the $\mathrm{f}^{2}$ values. Effect sizes also reconfirmed the strong effects of community evenness on RUE.

\section{DISCUSSION}

In this study we assessed the multivariate nature of BEF relationships in a natural phytoplankton community. By means of an SEM, we evaluated whe-

Cronbach's alpha also lay above their according threshold values of 0.6. Only the latent construct chemical conditions, including the indicator salinity, showed a Cronbach's alpha value (0.5316) below the recommended threshold. Our model also satisfied the Fornell-Larcker criterion (Table 3). According to the presented evaluation criteria, the measurement part of the model is reliable and represents the data well.

Table 4 displays the $\mathrm{R}^{2}$ and $\mathrm{Q}^{2}$ values for all endogenous latent constructs. Overall, the model showed high explanatory power for the variation measured in

Table 4. Evaluation criteria for validity of structural part of the model. For calculation and interpretation of these evaluation criteria, refer to Supplement 3. RUE: resource use efficiency

\begin{tabular}{|lcc|}
\hline & $\mathrm{R}^{2}$ & Stone-Geisser $\left(\mathrm{Q}^{2}\right)$ \\
\hline Biovolume & 0.8823 & 0.8224 \\
Evenness & 0.4447 & 0.3755 \\
RUE & 0.4313 & 0.3408 \\
Diversity & 0.2740 & 0.2037 \\
Nutrients & 0.5419 & 0.3174 \\
\hline
\end{tabular}

ther direct and indirect mechanisms found in experimental studies and analyses of terrestrial and freshwater data were likewise detectable in this highly dynamic marine ecosystem.

Table 5. Effect sizes $\left(\mathrm{f}^{2}\right)$ of all exogenous variables on the corresponding endogenous constructs. RUE: resource use efficiency

\begin{tabular}{|llc|}
\hline $\begin{array}{l}\text { Endogenous } \\
\text { variable }\end{array}$ & Exogenous variable & $\begin{array}{c}\text { Effect } \\
\text { size }\end{array}$ \\
\hline Biovolume & Diversity & 0.127 \\
& Evenness & 6.102 \\
& Solar energy & 0.441 \\
Evenness & Kinetic energy & 0.186 \\
& Nutrients & 0.490 \\
Nutrients & Chemical conditions & 0.043 \\
& Solar energy & 0.544 \\
Kinetic energy & 0.157 \\
& Chemical conditions & 0.537 \\
RUE & Nutrients & 0.138 \\
& Kinetic energy & 0.140 \\
& Evenness & 0.764 \\
\hline
\end{tabular}


Our results indicate that community evenness is the most prominent driver of phytoplankton productivity and RUE, yielding highly significant path coefficients (Fig. 2). This suggests that a few dominant species which exhibit certain physiological or stoichiometric advantages, and therefore outcompete many other species, are able to exploit the available resources more efficiently. Similar dominance effects were observed by Filstrup et al. (2014; our Fig. 1b) in their study on freshwater phytoplankton communities. The effect might be further enhanced by the fact that the 3 species with the largest cell sizes (Noctiluca scintillans: cell volume $=268 \times 10^{6} \mathrm{\mu m}^{3}$; Coscinodiscus

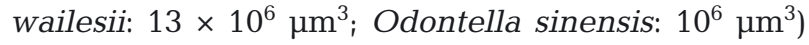
were also ranked first, second and sixth in the list of species with the highest mean biovolume values. Thus, our results support formerly stated assumptions that identities and characteristics of dominating species can have a substantial impact on BEF relationships (Bruno et al. 2005, Hillebrand et al. 2008). It should be noted that the maximal biovolume of the 2 biggest species ( $N$. scintillans and C. wailesii) exceeds the biovolume of most other present phytoplankton species by several magnitudes, which causes the biovolume measures to be highly influenced by these 2 species, although they are in fact rare in abundance as well as number of appearances throughout the year. However, an analysis of the data exclusive of these 2 species did not change the model results considerably.

For the effects of species richness on standing stock, the model returned significantly positive values, albeit less pronounced than the influence of community evenness. This indicates that although the identities of dominant species play a predominant role, species richness also significantly influences the shape of BEF relationships. Thus, while the majority of the biovolume might be maintained by a few species, the presence of additional species with potentially different traits enhances the communitywide biomass production. Our results therefore support respective findings of numerous BEF experiments (Fig. 1a).

The model did not support the hypothesis of an increase in RUE with increasing species number, as reported by Ptacnik et al. (2008) in their analysis of freshwater phytoplankton communities (Fig. 1a). However, the lowest genus richness level found in our study (22 genera) is considerably higher than the lowest genus numbers in their study $(<10)$. It is possible that above a certain threshold number of species or genera, RUE does not increase significantly and was therefore not detectable in our data set. Further differences could arise due to the fact that we used the mineral nutriments of the nutrients instead of total nutrients and that competition mechanisms differ between oligotrophic lakes and the rather eutrophic tidal flat area in our study. The fact that evenness and diversity show stronger effects on standing stock levels than on RUE values is in agreement with a recent meta-analysis of BEF experiments (Naeem et al. 2009), stating greater effects of diversity aspects on standing stock than on process rates.

With regard to the multivariate diversity-productivity hypothesis (Cardinale et al. 2009) (Fig. 1c), our results confirm the indirect effects of resource availability on biomass production via species richness. However, instead of a direct effect of resource availability on biomass, we again found that the amount of nutrients indirectly affects biovolume through the second aspect of species diversity, viz. evenness. This difference might be caused by the fact that Cardinale et al. (2009) included nitrogen, phosphorus, and PAR in 1 resource variable, whereas we distinguished between the 2 kinds of resources.

The model paths linking the environmental factors with diversity and the functional variables represent ecologically meaningful and reproducible mechanisms. Temperature and light showed significant positive effects on standing stock values. As light is known to be a limiting resource and temperature effects have likewise been proven to affect phytoplankton growth (Raven \& Geider 1988, Berges et al. 2002, Boyd et al. 2013), this result is consistent with current knowledge. We did not detect any direct impacts of light and temperature on either of the biodiversity aspects, which is consistent with the results of an indoor mesocosm meta-analysis by Lewandowska et al. (2012), who found no direct influence of temperature on phytoplankton evenness or species numbers.

The second environmental variable directly affecting the number of species was kinetic energy. We found significantly positive correlations between turbidity and the fraction of benthic species in the water body, which implies that higher turbidity reflects more intense mixing of the water body and can therefore be associated with higher species richness. In addition, turbidity is known to prevent dominance of a few species through the inhibition of optimal growth conditions (Oliver et al. 2010), which also promotes higher species numbers. The model's rather low explanatory power for species richness levels $\left(\mathrm{R}^{2}\right.$ value of 0.274$)$ and the non-significant influences of all other environmental variables imply that some important factors influencing species rich- 
ness have not been taken into account. These could possibly be different levels of grazing pressure (Prowe et al. 2012) or lateral exchange of water bodies (Clayton et al. 2013) which is not represented in the turbidity values.

Limitations of this approach are clearly that the model can only test relationships and directionalities which have been specified a priori. Moreover, it is constrained by the available data and the theoretical assumptions underlying the different pathways. Further variables such as predator abundance or more detailed measures of nutrient sources and supply may improve model performance. Additionally, SEM, as well as most other statistical methods, assumes linear relationships between 2 variables, although we did assess all pairwise relationships during exploratory data analysis before model construction. As stated earlier, partial least squares-based model estimations are rather robust against common issues like violation of distributional assumptions or sample size (Hulland et al. 2010).

Overall, regarding the good results for measurement model reliability and relatively high explanatory power for most of the endogenous variables, we are confident that the model identified valid relationships. The indicated patterns generally confirm observations made in experimental as well as observational studies on terrestrial and freshwater ecosystems, which suggests that a generalization of BEF patterns across ecosystems is at least possible to some extent.

\section{CONCLUSIONS}

The application of an SEM to the analysis of BEF relationships in a natural phytoplankton community showed that multivariate methods are not only an adequate tool, but also highly recommendable when investigating such complex networks of interactions. The model revealed a number of important indirect effects shaping the response of productivity to community diversity and environmental factors. Thus, we were able to identify patterns and mechanisms linking biodiversity and productivity in natural phytoplankton communities, which have so far mainly been described for experimental communities and have yet to be shown for marine phytoplankton in the field.

Acknowledgements. The Lower Saxony Ministry for Environment and Climate Protection and the Lower Saxony Ministry for Science and Culture funded this work as part of the collaborative research project WiMo ('Wissenschaftliche Monitoringkonzepte für die Deutsche Bucht').

\section{LITERATURE CITED}

Abdi H (2007) Partial least squares regression (PLS-regression). In: Salkind ND (ed) Encyclopedia of measurement and statistics. Sage, Thousand Oaks, CA, p 740-744

Arhonditsis GB, Stow CA, Steinberg LJ, Kenney MA, Lathrop RC, McBride SJ, Reckhow KH (2006) Exploring ecological patterns with structural equation modeling and Bayesian analysis. Ecol Model 192:385-409

Balvanera $\mathrm{P}$, Pfisterer $\mathrm{AB}$, Buchmann N, He JS, Nakashizuka T, Raffaelli D, Schmid B (2006) Quantifying the evidence for biodiversity effects on ecosystem functioning and services. Ecol Lett 9:1146-1156

Berges JA, Varela DE, Harrison PJ (2002) Effects of temperature on growth rate, cell composition and nitrogen metabolism in the marine diatom Thalassiosira pseudonana (Bacillariophyceae). Mar Ecol Prog Ser 225: 139-146

Boyd PW, Rynearson TA, Armstrong EA, Fu F and others (2013) Marine phytoplankton temperature versus growth responses from polar to tropical waters - outcome of a scientific community-wide study. PLoS ONE 8:e63091

$>$ Braarud T (1951) Salinity as an ecological factor in marine phytoplankton. Physiol Plant 4:28-34

$>$ Bruno JF, Boyer KE, Duffy JE, Lee SC, Kertesz JS (2005) Effects of macroalgal species identity and richness on primary production in benthic marine communities. Ecol Lett 8:1165-1174

Cardinale BJ, Srivastava DS, Duffy JE, Wright JP, Downing AL, Sankaran M, Jouseau C (2006) Effects of biodiversity on the functioning of trophic groups and ecosystems. Nature 443:989-992

> Cardinale BJ, Hillebrand H, Harpole WS, Gross K, Ptacnik R (2009) Separating the influence of resource 'availability' from resource 'imbalance' on productivity-diversity relationships. Ecol Lett 12:475-487

Cardinale BJ, Matulich KL, Hooper DU, Byrnes JE and others (2011) The functional role of producer diversity in ecosystems. Am J Bot 98:1-21

> Cardinale BJ, Duffy JE, Gonzalez A, Hooper DU and others (2012) Biodiversity loss and its impact on humanity. Nature 486:59-67

> Clayton S, Dutkiewicz S, Jahn O, Follows MJ (2013) Dispersal, eddies, and the diversity of marine phytoplankton. Limnol Oceanogr Fluids Environ 3:182-197

Colijn F, van Beusekom J (2005) Effect of eutrophication on phytoplankton productivity and growth in the Wadden Sea. In: Wilson JC (ed) The intertidal ecosystem: the value of Ireland's shores. Royal Irish Academy, Dublin, p 58-68

> Diehl S (2002) Phytoplankton, light, and nutrients in a gradient of mixing depths: theory. Ecology 83:386-398

Egge JK, Aksnes DL (1992) Silicate as regulating nutrient in phytoplankton competition. Mar Ecol Prog Ser 83: 281-289

Esposito Vinzi V, Chin WW, Henseler J, Wang H (eds) (2010) Handbook of partial least squares. Springer Handbooks of Computational Statistics. Springer, Heidelberg

Filstrup CT, Hillebrand H, Heathcote AJ, Harpole WS, Downing JA (2014) Cyanobacteria dominance influences resource use efficiency and community turnover in phytoplankton and zooplankton communities. Ecol Lett 17:464-474

Götz O, Liehr-Gobbers K, Krafft M (2010) Evaluation of structural equation models using the partial least squares (PLS) approach. In: Esposito Vinzi V, Chin WW, Henseler 
J, Wang $\mathrm{H}$ (eds) Handbook of partial least squares. Springer Handbooks of Computational Statistics. Springer, Heidelberg, p 691-711

Grace JB, Anderson TM, Olff H, Scheiner SM (2010) On the specification of structural equation models for ecological systems. Ecol Monogr 80:67-87

Grunwald M, Dellwig O, liebezeit G, Schnetger B, Reuter R, Brumsack HJ (2007) A novel time-series in the Wadden sea (NW Germany): first results on continuous nutrient and methane measurements. Mar Chem 107:411-421

Haenlein M, Kaplan AM (2004) A beginner's guide to partial least squares analysis. Underst Stat 3:283-297

Harman HH (1976) Modern factor analysis. University of Chicago Press, Chicago, IL

Hillebrand H, Matthiessen B (2009) Biodiversity in a complex world: consolidation and progress in functional biodiversity research. Ecol Lett 12:1405-1419

- Hillebrand H, Duerselen CD, Kirschtel D, Pollingher U, Zohary $\mathrm{T}$ (1999) Biovolume calculation for pelagic and benthic microalgae. J Phycol 35:403-424

Hillebrand H, Bennett DM, Cadotte MW (2008) Consequences of dominance: a review of evenness effects on local and regional ecosystem processes. Ecology 89: $1510-1520$

Hulland J (1999) Use of partial least squares (PLS) in strategic management research: a review of four recent studies. Strateg Manag J 20:195-204

Hulland J, Ryan MJ, Rayner RK (2010) Modeling customer satisfaction: a comparative performance evaluation of covariance structure analysis versus partial least squares. In: Esposito Vinzi V, Chin WW, Henseler J, Wang $\mathrm{H}$ (eds) Handbook of partial least squares. Springer Handbooks of Computational Statistics. Springer, Heidelberg, p 307-325

Interlandi SJ, Kilham SS (2001) Limiting resources and the regulation of diversity in phytoplankton communities. Ecology 82:1270-1282

Korhonen JJ, Wang J, Soininen J (2011) Productivity-diversity relationships in lake plankton communities. PLoS ONE 6:e22041

> Lewandowska AM, Breithaupt P, Hillebrand H, Hoppe HG, Jürgens K, Sommer U (2012) Responses of primary productivity to increased temperature and phytoplankton diversity. J Sea Res 72:87-93

Lionard M, Muylaert K, van Gansbeke D, Vyverman W (2005) Influence of changes in salinity and light intensity on growth of phytoplankton communities from the Schelde river and estuary (Belgium / The Netherlands). Hydrobiologia 540:105-115

Lohmöller JB (1989) Latent variable path modeling with partial least squares. Physica-Verlag, Heidelberg

- Martin-Jézéquel V, Hildebrand M, Brzezinski MA (2000) Silicon metabolism in diatoms: implications for growth. J Phycol 36:821-840

> Naeem S, Lawton JH, Thompson LJ, Lawler SP, Woodfin RM (1995) Biotic diversity and ecosystem processes: using the Ecotron to study a complex relationship. Endeavour 19:58-63

Naeem S, Bunker DE, Hector A, Loreau M, Perrings C (eds) (2009) Biodiversity, ecosystem functioning and human wellbeing. An ecological and economic perspective. Oxford University Press, New York, NY

O'Brien RM (2007) A caution regarding rules of thumb for

Editorial responsibility: Graham Savidge,

Portaferry, UK variance inflation factors. Qual Quant 41:673-690

Olenina I, Hajdu S, Edler L, Andersson A and others (2006) Biovolumes and size-classes of phytoplankton in the Baltic Sea. HELCOM Balt Sea Environ Proc 106

Oliver RL, Mitrovic SM, Rees C (2010) Influence of salinity on light conditions and phytoplankton growth in a turbid river. River Res Appl 26:894-903

Pielou EC (1966) The measurement of diversity in different types of biological collections. J Theor Biol 13:131-144

> Pimm SL, Jenkins CN, Abell R, Brooks TM and others (2014) The biodiversity of species and their rates of extinction, distribution, and protection. Science 344:1246752

Prowe AEF, Pahlow M, Dutkiewicz S, Follows M, Oschlies A (2012) Top-down control of marine phytoplankton diversity in a global ecosystem model. Prog Oceanogr 101: $1-13$

> Ptacnik R, Solimini AG, Andersen T, Tamminen T and others (2008) Diversity predicts stability and resource use efficiency in natural phytoplankton communities. Proc Natl Acad Sci USA 105:5134-5138

R Development Core Team (2010) R: a language and environment for statistical computing. R Foundation for Statistical Computing, Vienna

Raven JA, Geider RJ (1988) Temperature and algal growth. New Phytol 110:441-461

Reid PC, Lancelot C, Gieskes WWC, Hagmeier E, Wecihart G (1990) Phytoplankton of the North Sea and its dynamics: a review. Neth J Sea Res 26:295-331

Reuter R, Badewien TH, Bartholomä A, Braun A, Lübben A, Rullkötter J (2009) A hydrographic time series station in the Wadden Sea (southern North Sea). Ocean Dyn 59: 195-211

Ringle CM, Wende S, Will A (2005) SmartPLS 2.0 (beta). Available at www.smartpls.com/

Schallenberg M, Burns CW (2004) Effects of sediment resuspension on phytoplankton production: teasing apart the influences of light, nutrients and algal entrainment. Freshw Biol 49:143-159

Shannon C, Weaver W (1949) The mathematical theory of communication. The University of Illinois Press, Urbana, IL

Striebel M, Behl S, Diehl S, Stibor H (2009) Spectral niche complementarity and carbon dynamics in pelagic ecosystems. Am Nat 174:141-147

Thamdrup B, Würgler Hansen J, Jorgensen BB (1998) Temperature dependence of aerobic respiration in a coastal sediment. FEMS Microbiol Ecol 25:189-200

> Tilman D, Wedin D, Knops J (1996) Productivity and sustainability influenced by biodiversity in grassland ecosystems. Nature 379:718-720

UNESCO (1985) The international system of units (SI) in oceanography. Tech Pap Mar Sci 45. UNESCO, Paris

Utermöhl H (1958) Zur Vervollkommnung der quantitativen Phytoplankton-Methodik. Schweizerbart'sche Verlagsbuchhandlung, Stuttgart

> Vallina SM, Follows MJ, Dutkiewicz S, Montoya JM, Cermeno P, Loreau M (2014) Global relationship between phytoplankton diversity and productivity in the ocean. Nat Commun 5:4299

> Wold S, Ruhe A, Wold H, Dunn WJ III (1984) The collinearity problem in linear regression. The partial least squares (PLS) approach to generalized inverses. SIAM J Sci Stat Comput 5:735-743

Submitted: May 28, 2014; Accepted: December 3, 2014 Proofs received from author(s): March 2, 2015 